\title{
Biantennary oligoglycines and glyco-oligoglycines self-associating in aqueous medium
}

\author{
Svetlana V. Tsygankova ${ }^{1}$, Alexander A. Chinarev ${ }^{1}$, Alexander B. Tuzikov ${ }^{1}$, \\ Nikolai Severin ${ }^{2}$, Alexey A. Kalachev ${ }^{3}$, Juergen P. Rabe ${ }^{2}$, \\ Alexandra S. Gambaryan ${ }^{4}$ and Nicolai V. Bovin ${ }^{* 1}$
}

\section{Full Research Paper}

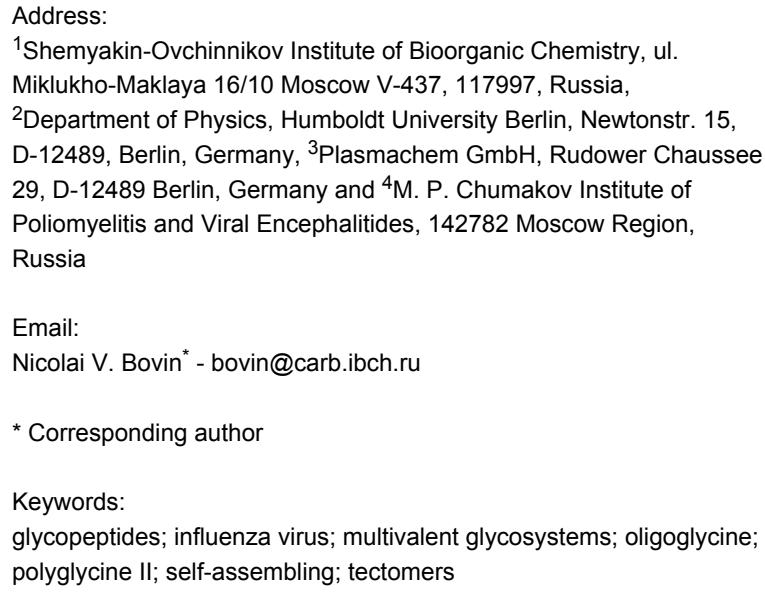

${ }^{1}$ Shemyakin-Ovchinnikov Institute of Bioorganic Chemistry, ul. Miklukho-Maklaya 16/10 Moscow V-437, 117997, Russia,

2Department of Physics, Humboldt University Berlin, Newtonstr. 15,

D-12489, Berlin, Germany, ${ }^{3}$ Plasmachem GmbH, Rudower Chaussee

29, D-12489 Berlin, Germany and ${ }^{4}$ M. P. Chumakov Institute of

Poliomyelitis and Viral Encephalitides, 142782 Moscow Region,

Russia

Email:

Nicolai V. Bovin* - bovin@carb.ibch.ru

${ }^{*}$ Corresponding author

Keywords:

glycopeptides; influenza virus; multivalent glycosystems; oligoglycine; polyglycine II; self-assembling; tectomers

Open Access

\author{
Beilstein J. Org. Chem. 2014, 10, 1372-1382. \\ doi:10.3762/bjoc. 10.140
}

Received: 28 February 2014

Accepted: 09 May 2014

Published: 17 June 2014

This article is part of the Thematic Series "Multivalent glycosystems for nanoscience". A part of this work was presented at 17th European Carbohydrate Symposium "EuroCarb17" [1].

Guest Editor: B. Turnbull

(C) 2014 Tsygankova et al; licensee Beilstein-Institut. License and terms: see end of document.

\begin{abstract}
Oligoglycines designed in a star-like fashion, so-called tri- and tetraantennary molecules, were found to form highly ordered supramers in aqueous medium. The formation of these supramers occurred either spontaneously or due to the assistance of a mica surface. The driving force of the supramer formation is hydrogen bonding, the polypeptide chain conformation is related to the folding of helical polyglycine II (PG II). Tri- and tetraantennary molecules are capable of association if the antenna length reach 7 glycine (Gly) residues. Properties of similar biantennary molecules have not been investigated yet, and we compared their selfaggregating potency with similar tri- and tetraantennary analogs. Here, we synthesized oligoglycines of the general formula R-Gly ${ }_{n}-\mathrm{X}-\mathrm{Gly}_{n}-\mathrm{R}\left(\mathrm{X}=-\mathrm{HN}-\left(\mathrm{CH}_{2}\right)_{m}-\mathrm{NH}-, m=2,4,10 ; n=1-7\right)$ without pendant ligands $(\mathrm{R}=\mathrm{H})$ and with two pendant sialoligands $(\mathrm{R}=$ sialic acid or sialooligosaccharide). Biantennary oligoglycines formed PG II aggregates, their properties, however, differ from those of the corresponding tri- and tetraantennary oligoglycines. In particular, the tendency to aggregate starts from $\mathrm{Gly}_{4}$ motifs instead of Gly ${ }_{7}$. The antiviral activity of end-glycosylated peptides was studied, and all capable of assembling glycopeptides demonstrated an antiviral potency which was up to 50 times higher than the activity of peptide-free glycans.
\end{abstract}

\section{Introduction}

Recently, we have synthesized and described tetraantennary [2] and triantennary [3] oligoglycines capable of spontaneous or surface-promoted formation of flat layers in aqueous medium.
These layers are one or two molecules thick. The stability was attributed to the formation of a network of hydrogen bonds. This class of supramers has been called tectomers. Tectomers in 
a layer are packed by polyglycine II type (PG II) [4,5]. Their helical polypeptide chain fundamentally differs from the canonical $\alpha$-helix. The association of symmetrical tetra- and triantennary (star-like) oligoglycines spontaneously proceeds only when the number of glycine (Gly) residues in a chain $(n)$ is equal or greater to seven. Oligoglycines with an antennae size less than seven do either not associate at all or require extremely favorable conditions, in particular surface promotion. Yet, the properties of similar biantennary molecules were not investigated. Here, we synthesized biantennary oligoglycines and studied them in order to determine the necessary and sufficient conditions for self-association. More specifically, we investigated the combination of structure elements, such as the $n$ value, the type of terminal substituents, and the type of struc- tural motifs (core), where the antennae are connected to each other. The knowledge of the rules found for the unsubstituted assembly of oligoglycines may be suitable for us for the design of corresponding sialo derivartives, which are candidate therapeutics for the blocking of the influenza virus [6].

\section{Results and Discussion Synthesis of biantennary oligoglycines and their glyco derivatives}

The synthesized biantennary oligoglycines and their glyco derivatives are presented in Figure 1. Analogously to tri- and tetraantennary molecules, oligoglycine antennas are connected according to the 'head-to-head' principle, i.e., by their C-termini, so that the two amino groups are terminal. The

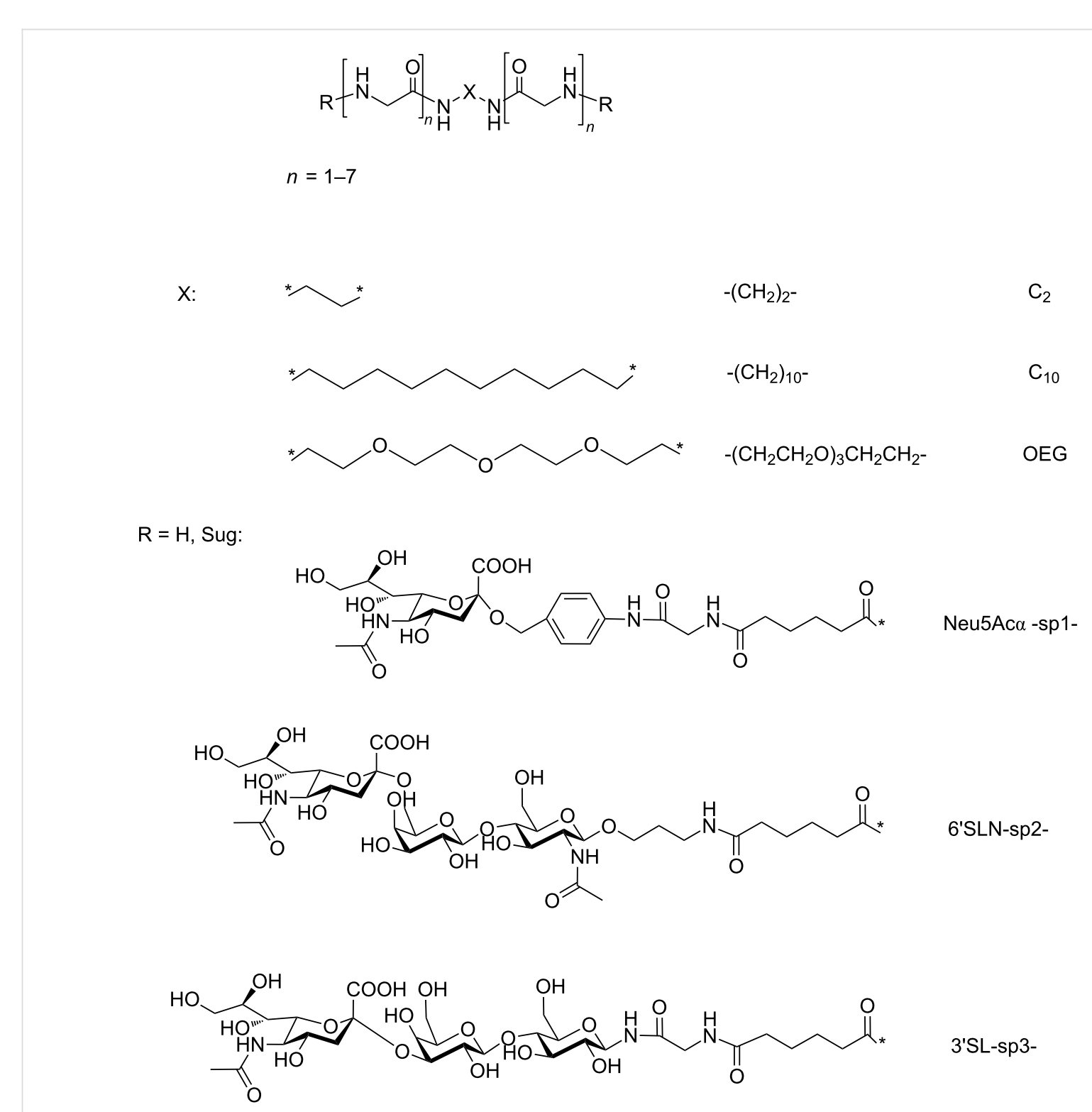


obtained compounds differ threefold. Firstly, they differ by core $\mathrm{X}$ nature: hydrophilic oligoethylene glycol (OEG), hydrophobic flexible decamethylene $\left(\mathrm{C}_{10}\right)$, or short ethylene $\left(\mathrm{C}_{2}\right)$. Secondly, the length of oligoglycine antennas, i.e., the number of glycine residues in a chain $(n=1-7)$ is different. Thirdly, the substances differ by the presence or absence of carbohydrate fragment (Sug), containing $\alpha-N$-acetylneuraminic moiety (Neu5Ac $\alpha$ ).

Diamines $\mathrm{NH}_{2}-\mathrm{X}-\mathrm{NH}_{2}$ were the starting substances for the synthesis, oligoethylene glycol diamine was obtained from ditosylate as described in $[7,8]$. The synthesis of biantennary oligoglycines was carried out by means of the activated esters method (Scheme 1) [9]. The glycine chains were elongated stepwise by their $\mathrm{N}$-terminus by using $\mathrm{N}$-oxysuccinimidyl esters (BocGlyONSu or BocGly 2 ONSu, Boc = tert-butyloxycarbonyl). Boc-peptides were isolated from the reaction mixture by the removal of the solvent and the re-crystallization of the reaction product from aqueous methanol (yields 75-95\%). In the case of poorly soluble products the impurities and starting materials were washed off with methanol (yields 60-90\%). In the case of an oil-like substance ( $\mathrm{X}=\mathrm{OEG}, n=2$ ) chromatography on silica gel was performed. The quantitative removal of Boc groups was achieved by the treatment of the obtained peptides with trifluoroacetic acid. Salt forms (trifluoroacetates or hydrochlorides) of diamino derivatives were obtained by sedimentation from an aqueous solution by methanol (yield $\geq 95 \%$ ). At later stages of elongation the salts were converted to the respective free bases by treatment with a slight excess of triethylamine. The preparation of oligoglycines with a chain length exceeding five glycine residues for the derivatives with core $\mathrm{C}_{10}$ and six residues for core $\mathrm{C}_{2}$ failed due to their low solubility and, consequently, the impossibility of separating them from the intermediates of the synthesis.

Sialo conjugates of biantennary oligoglycines were obtained from the corresponding diamines and derivatives of $\alpha$ - $N$-acetyl- neuraminic acid (Sug-ONp), where the carboxyl group of the spacer was activated with 4-nitrophenol (Np) (Scheme 1). The synthesis of these compounds was described in [10,11]. Owing to the poor solubility of the diamine form of oligoglycines with cores $\mathrm{C}_{2}$ and $\mathrm{C}_{10}$ in DMSO, the reaction was carried out in a saturated aqueous solution of lithium bromide, which prevented the formation of hydrogen bonds and thus increased the solubility of oligoglycines. Glycopeptides were isolated from the reaction mixture by gel-permeation chromatography (yields 70-75\%). The peptide modification by the amino group with mono- or oligosaccharides dramatically increased their solubility in water. This may support their antiviral action (see below), because glycopeptides act topically, in the respiratory tract, and are administered as a spray.

We then investigated the ability of synthesized biantennary oligoglycines to assemble in aqueous media as well as the antiviral activity of glycoderivatives.

\section{Study of biantennary oligoglycines associ- ation in solution by dynamic light scattering}

The size of the particles formed by the biantennary oligoglycines in solution was measured with the dynamic light scattering method (DLS). We found that the ability of association depends on the number of the glycine units in the antennae, the nature of the core, the $\mathrm{pH}$, and the peptide concentration.

It is known that the charge of terminal amino groups of the protonated form of oligoglycines hinders association. To overcome this obstacle an equimolar quantity of $\mathrm{NaHCO}_{3}$ or $\mathrm{Na}_{2} \mathrm{CO}_{3}$ was added to aqueous solutions of oligoglycine salts. In the absence of the base, $\mathrm{pH}$ values of oligoglycine salt solutions varied from 3.5 to 4.5 (hereinafter denoted as $\mathrm{pH}<5$ ). In the case of the addition of one base equivalent per one amino group the solution becomes neutral ( $\mathrm{pH}$ 6.5), in the case of two $\mathrm{Na}_{2} \mathrm{CO}_{3}$ equivalents the $\mathrm{pH}$ value is more than 8.5 (basic solution, denoted as $\mathrm{pH}>8.5$ ).

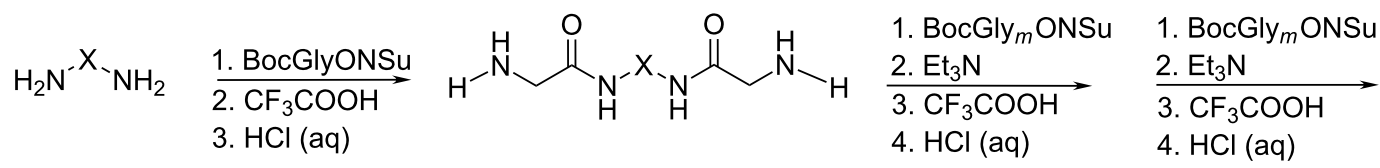

\section{2. $\mathrm{Et}_{3} \mathrm{~N}$ \\ 3. $\mathrm{CF}_{3} \mathrm{COOH}$}

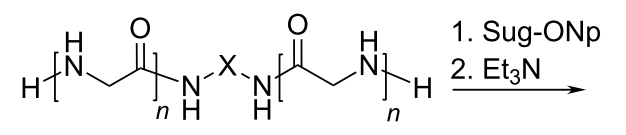

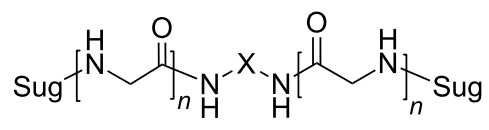

$$
\begin{gathered}
n=1-7 \\
m=1-2
\end{gathered}
$$<smiles>N#Cc1ccc([N+](=O)[O-])cc1</smiles> 
At $n<4$ peptides with an oligoethylene glycol core and the cores $\mathrm{C}_{2}$ and $\mathrm{C}_{10}$ did not form associates in aqueous medium in all the studied ranges of $\mathrm{pH}$ and concentration $(0.1-1.0 \mathrm{mg} / \mathrm{mL})$.

Biantennary oligoglycines, cores $\mathrm{C}_{2}$ and $\mathrm{C}_{10}, n \geq 4$, are capable of forming associates $(700-900 \mathrm{~nm})$ in acidic solutions in the studied concentration range, except for $\mathrm{H}-\mathrm{Gly}_{4} \mathrm{NH}\left(\mathrm{CH}_{2}\right)_{10} \mathrm{NHGly}_{4}-\mathrm{H} \cdot 2 \mathrm{HCl}$, which associates in concentrations $\geq 0.5 \mathrm{mg} / \mathrm{mL}$.

Molecules with the core $\mathrm{C}_{2}(n=4-6)$ and $\mathrm{C}_{10}(n=5)$ associate so rapidly in neutral and basic media that a precipitate is formed (data for peptide with $n=5$ are given in Figure 2a). Only the peptide $\mathrm{H}-\mathrm{Gly}_{4} \mathrm{NH}\left(\mathrm{CH}_{2}\right)_{10} \mathrm{NHGly}_{4}-\mathrm{H}$ in concentration $\leq 0.1 \mathrm{mg} / \mathrm{mL}$ is capable of forming associates $(800-1200 \mathrm{~nm})$ stable in aqueous media (Figure 2a,b).

\section{Study of biantennary peptides association using scanning force microscopy}

Scanning force microscopy (SFM) elucidates information not only about the association process both in solution and on a surface, but also about fine details of the formed architectures. Of particular interest are cases characterized by the active participation of the surface in accelerating the self-assembly. To discriminate the processes taking place on the surface from similar processes in liquid volume, measurements were carried out immediately after the deprotonation of oligoglycine salts at incubation times insufficient for a spontaneous association in solution (found out as $\leq 1 \mathrm{~min}$ ). The solution was placed on a freshly cleaved surface of mica or graphite, exposed for fixed time intervals (denoted as $t_{\text {exp }}$ ), followed by the removal of the liquid phase from the surface and the scanning of the sample in tapping mode in air. The contact mode of scanning was used for experiments in a liquid cell. Experiments in a liquid cell allowed us to study the kinetics of the process without a possible distortion of the nanostructures resulting from the drying of the sample.

The Raman spectra (Figure 3) of biantennary oligoglycines capable of association as well as the spectra of tri- and tetraantennary peptides described earlier display bands at 884,1261 , 1382, 1424 and $1654 \mathrm{~cm}^{-1}$, which are characteristic and specific for crystalline PG II. Based on the presence of these bands we conclude that the structure organization of associates formed in solution corresponds to PG II. The sensitivity of routine Raman scattering method is insufficient for the work with oligoglycine monolayers, so indirect methods were used in order to attribute formed material to a PG II structure. More specifically, geometrical parameters of the layers were determined by using SFM and compared with: 1) those for tectomers (attributed to PG II, see above) formed in solution and 2) calculated values for different, not only PG II, models. As shown below for particular examples, in most cases spontaneous and surface-mediated assembly led to associates of PG II structure, i.e., tectomers.

The formation of the PG II structure for oligoglycines with a short rigid spacer $\mathrm{C}_{2}$ is only possible if the molecule is extended, i.e., antennas are pointing in opposite directions (conformation " $1+1$ ", Figure 4a). The presence of a flexible core $\left(\mathrm{C}_{10}, \mathrm{OEG}\right)$ allows the molecule to adopt the conformation " $2+0$ ", which is characterized by unidirectional oligoglycine antennas. The hydrophobic side of the tectomer should initiate the formation of the second layer with the opposite orientation a)

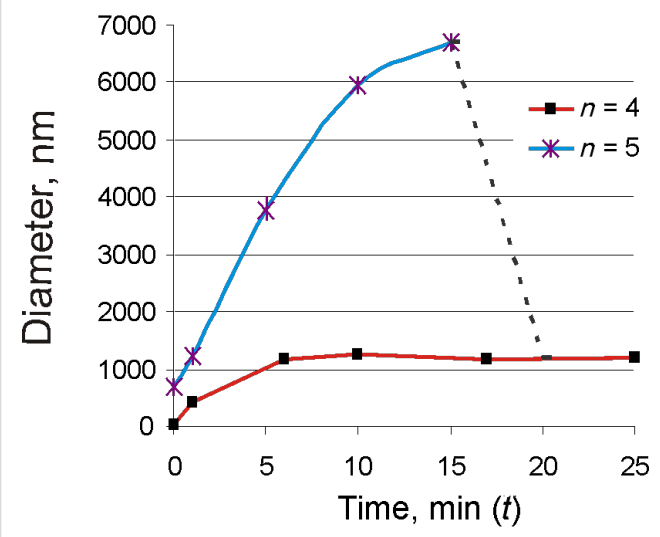

b)

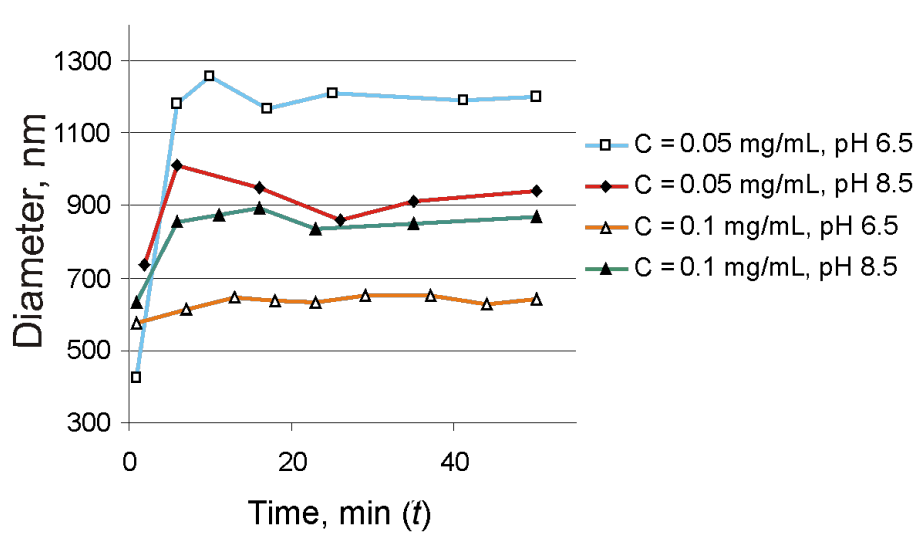

Figure 2: Dynamics of associate formation by biantennary oligoglycines $\mathrm{H}-\mathrm{Gly} n-\mathrm{NH}\left(\mathrm{CH}_{2}\right){ }_{10} \mathrm{NH}-\mathrm{Gly} n-\mathrm{H}$. a) $n=4-5$, in aqueous solution at pH 6.5 and a concentration of $0.1 \mathrm{mg} / \mathrm{mL}$ at $t=0$ and $\mathrm{pH}<5$ before the addition of base and at $t>0$ and $\mathrm{pH} 6.5$ after the addition of base. The region of sedimentation is marked with a dotted line. b) $n=4$, in aqueous solution at $\mathrm{pH} 6.5$ and 8.5 . 


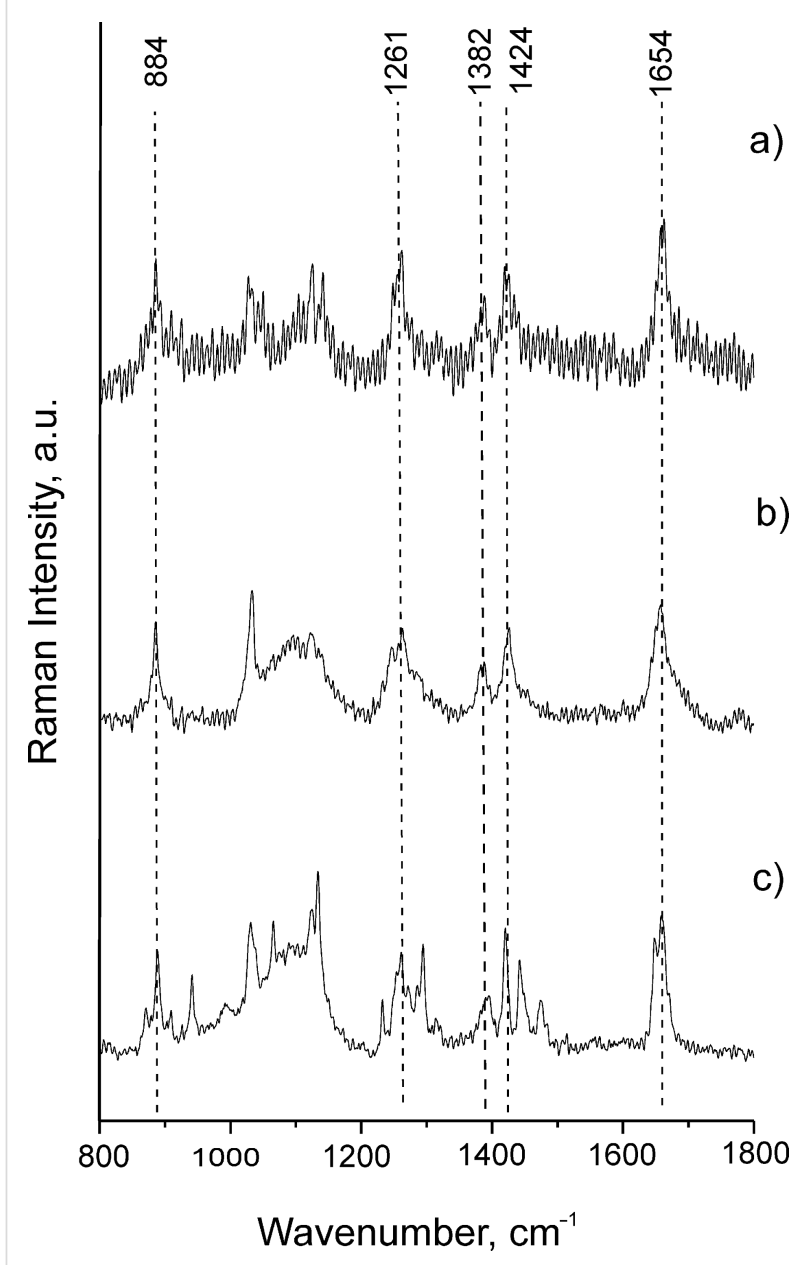

Figure 3: Raman spectra of a) [H-Gly $\left.7-\mathrm{NHCH}_{2}\right]_{4} \mathrm{C}$; b) $\mathrm{H}-\mathrm{Gly}_{4}-$ $\mathrm{NH}\left(\mathrm{CH}_{2}\right)_{2} \mathrm{NH}-\mathrm{Gly} 4-\mathrm{H}$; c) H-Gly $4-\mathrm{NH}\left(\mathrm{CH}_{2}\right){ }_{10} \mathrm{NH}-\mathrm{Gly}_{4}-\mathrm{H}$. The spectra contain characteristic bands at $884,1261,1382,1424$ and $1654 \mathrm{~cm}^{-1}$ corresponding to the structure PG II [12]. Spectra were recorded for the samples in solid phase. of the monomer in aqueous solutions (Figure 4b) in order to minimize the thermodynamically unfavorable contact with water.

a) It was demonstrated for biantennary oligoglycines that a concentration of $0.1 \mathrm{mg} / \mathrm{mL}$ is optimal for the study of the dynamics of tectomer growth on a mica surface. At higher concentrations the growth both in solution and on the surface proceeded so rapidly that the dynamics study was considered impossible. No tectomer structure was observed under acidic conditions $(\mathrm{pH}<5)$, whereas under neutral and basic conditions the reaction proceeded similarly in terms

b) of both the velocity and the morphology of formed tectomers. The oligoethylene glycol derivatives $\mathrm{H}-\mathrm{Gly}_{n^{-}}$ $\mathrm{NH}\left(\mathrm{CH}_{2} \mathrm{CH}_{2} \mathrm{O}\right)_{3} \mathrm{CH}_{2} \mathrm{CH}_{2} \mathrm{NH}-\mathrm{Gly}_{n}-\mathrm{H}(n=2-7)$, non-associating in aqueous solutions as well as oligoglycines with cores $\mathrm{C}_{2}$ and $\mathrm{C}_{10}(n<4)$ did not form associates on a mica surface under all studied ranges of $\mathrm{pH}$ (from 4.5 to 8.5).

According to dynamic light scattering data (see above) only peptide $\mathrm{H}-\mathrm{Gly}_{4} \mathrm{NH}\left(\mathrm{CH}_{2}\right)_{10} \mathrm{NHGly}_{4}-\mathrm{H}$ was capable of forming tectomers in neutral and basic solutions which were unchanged in an aqueous phase for a long time. Figure 5 demonstrates the dynamics of layer growth on mica with the characteristic formation of islet structures $\left(t_{\exp }=0.5 \mathrm{~min}\right.$, Figure $5 \mathrm{a}$ ), growing laterally $\left(t_{\exp }=1 \mathrm{~min}\right.$, Figure $\left.5 \mathrm{~b}\right)$, and covering the whole surface with an even layer $\left(t_{\exp }=2 \mathrm{~min}\right.$, Figure $\left.5 \mathrm{c}\right)$. Presumably, longer times $\left(t_{\exp }>2 \mathrm{~min}\right)$ are characterized by the appearance of multilayer tectomers resulting from the sorption of associates formed in solution. The multilayer tectomers can be readily removed by washing with buffer solution ( $\mathrm{pH} 6.5$ or 9.0). The morphology of the first layer remains unchanged and the available defects ('holes') are preserved. The layer height is $3.7-4.0 \mathrm{~nm}$, which may correspond to both mono- and bilayer (conformations " $1+1$ " and " $2+0$ ", respectively, see Figure 4).

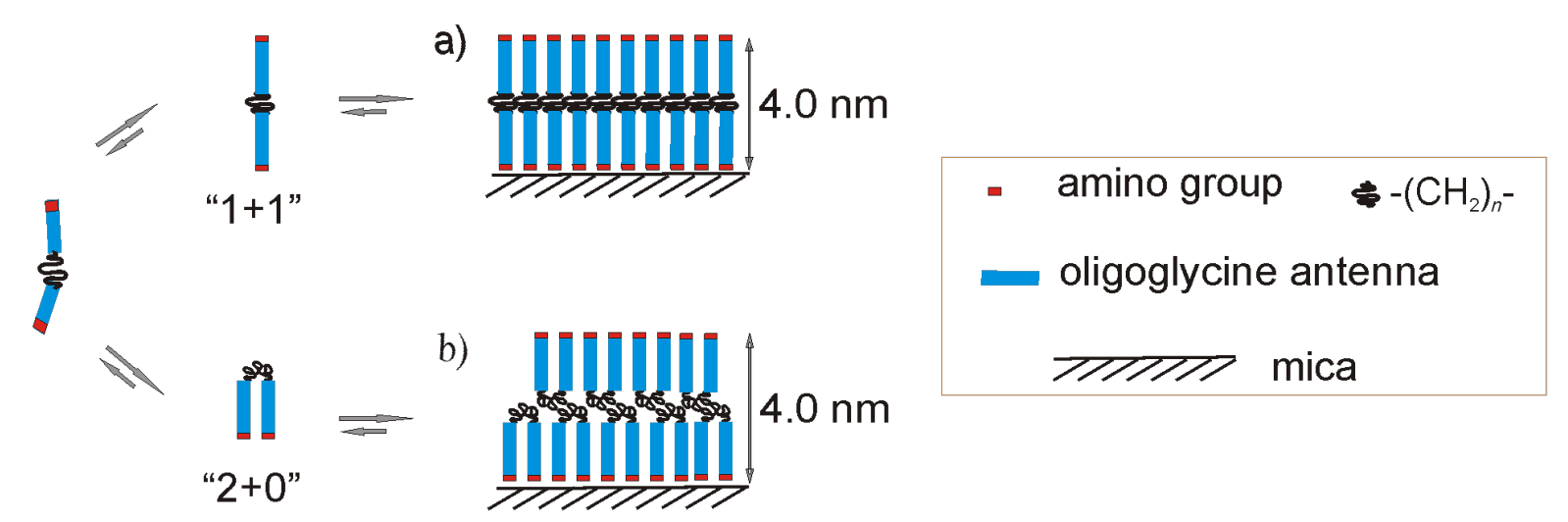

Figure 4: Model of the formation of tectomer layers by biantennary oligoglycines on a mica surface. The heights are given for $\mathrm{H}-\mathrm{Gly}{ }_{4} \mathrm{NH}\left(\mathrm{CH}_{2}\right)_{10} \mathrm{NHGly}_{4}-\mathrm{H}$. 
a)

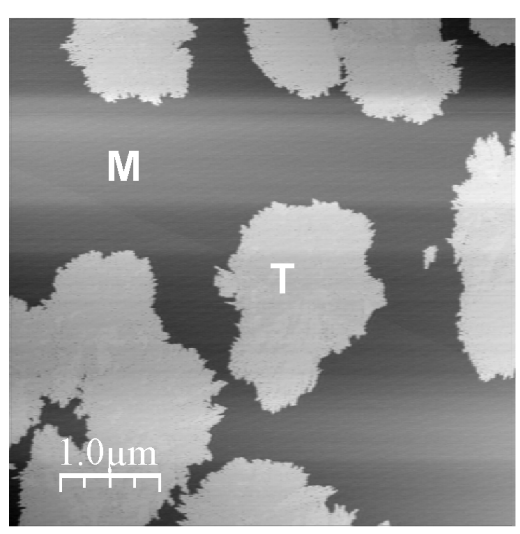

b)

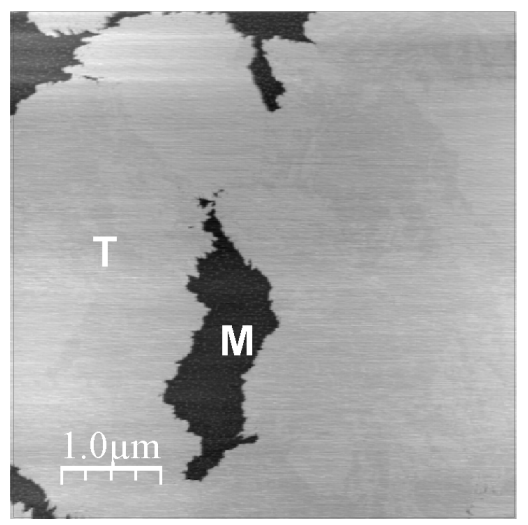

c)

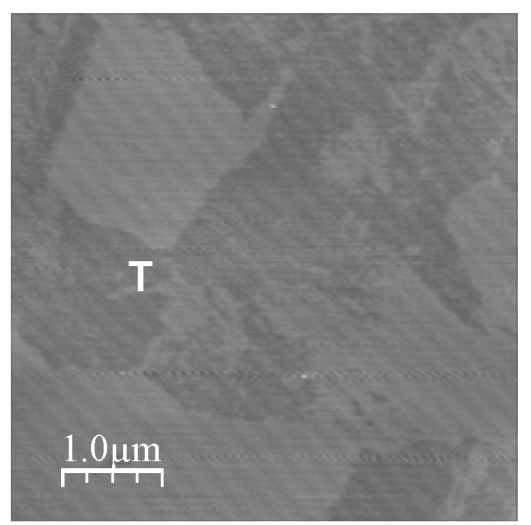

Figure 5: Growth of the tectomer formed by the peptide $\mathrm{H}-\mathrm{Gly}_{4}-\mathrm{NH}\left(\mathrm{CH}_{2}\right)_{10}-\mathrm{NHGly} 4-\mathrm{H}$ (concentration $0.1 \mathrm{mg} / \mathrm{mL}$ ) on a mica surface at pH 6.5, with tapping mode, SFM on air, and a $t_{\exp }$ of a) $0.5 \mathrm{~min}$, b) $1 \mathrm{~min}$, c) $2 \mathrm{~min}$. Here, the shown field is completely covered with tectomer layer; its roughness found to be $\pm 0.1 \mathrm{~nm}$. T indicates the tectomer layer, $M$ the uncovered mica regions.

The dynamics of $\mathrm{H}-\mathrm{Gly}_{4} \mathrm{NH}\left(\mathrm{CH}_{2}\right)_{10} \mathrm{NHGly}_{4}-\mathrm{H}$ association was studied in more detail in a liquid cell (Figure 6). After 3 min the surface was virtually completely covered with a uniform defectfree layer. It should be noted that the stepwise surface profile (typical for bilayer structures) was not observed in a liquid cell. The layer morphology was identical to the one observed in experiments in air (Figure 5).

Dynamic light scattering data give evidence that in neutral aqueous solutions the association of compounds $\mathrm{H}-\mathrm{Gly}_{5}-\mathrm{NH}-\mathrm{X}-$ $\mathrm{NH}-\mathrm{Gly}_{5}-\mathrm{H}$ (cores $\mathrm{C}_{2}$ and $\mathrm{C}_{10}$ ) leads to the formation of large aggregates. By means of SFM it was demonstrated that the peptide with core $\mathrm{C}_{2}$ formed islet-like tectomers on mica surface $\left(t_{\exp }=10 \mathrm{~min}\right)$ with a height of $3.3 \mathrm{~nm}$ and planar dimensions of 500-700 nm (Figure 7a). The compound with core $\mathrm{C}_{10}$ associated more rapidly (Figure $7 \mathrm{~b}$ ), though the surface was not completely covered $\left(t_{\exp }=10 \mathrm{~min}\right)$. This is in contrast to the structure analog with four glycines in the antenna, where a time period of only two minutes was sufficient for complete covering. The measured heights fit the model " $1+1 "$.

The obtained data give evidence that mica promotes the formation of tectomers from biantennary oligoglycines in neutral and basic solutions. Layer growth proceeds due to the surface co-participation. In the case of the molecule ${\mathrm{H}-\mathrm{Gly}_{4}-}^{-}$ $\mathrm{NH}\left(\mathrm{CH}_{2}\right)_{10} \mathrm{NH}-\mathrm{Gly}_{4}-\mathrm{H}$ growth continues until the surface is completely covered, whereas in the bulk of the liquid phase a)

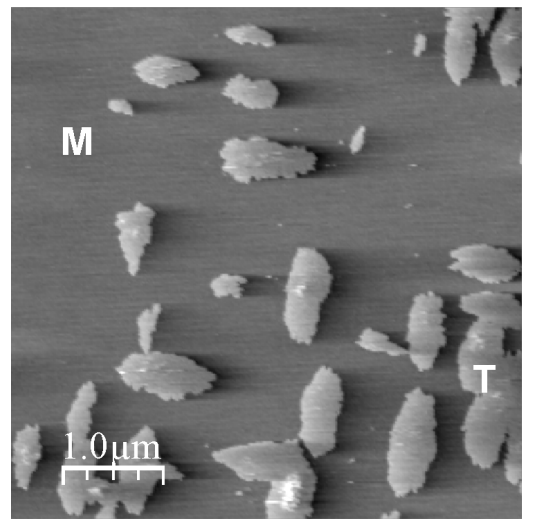

b)

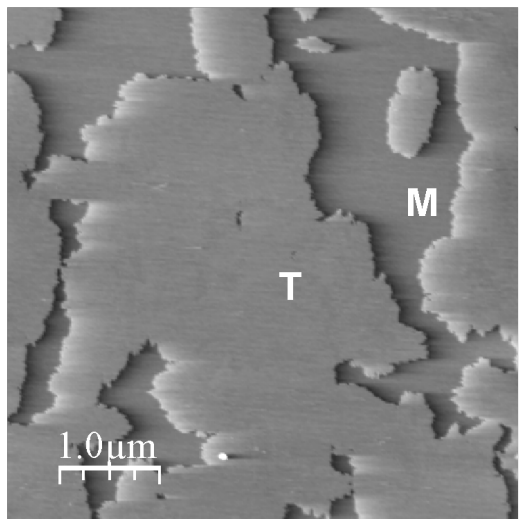

c)

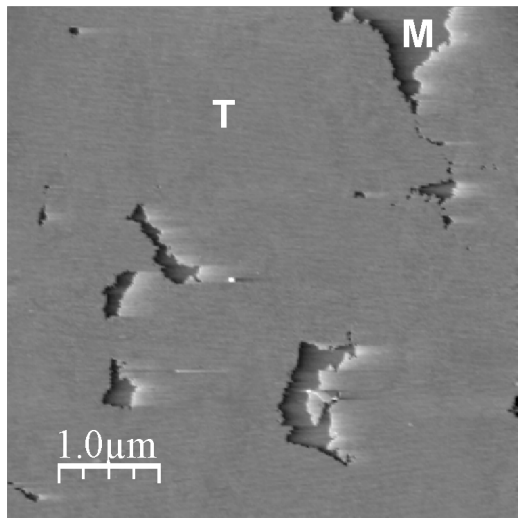

Figure 6: Growth of the tectomer formed by peptide $\mathrm{H}-\mathrm{Gly}_{4}-\mathrm{NH}\left(\mathrm{CH}_{2}\right){ }_{10} \mathrm{NH}-\mathrm{Gly} 4-\mathrm{H}$ (concentration $0.1 \mathrm{mg} / \mathrm{mL}$ ) on a mica surface in a liquid cell at pH 6.5. Phase SFM images were taken with a) $\left.t_{\exp }=1 \mathrm{~min}, \mathrm{~b}\right) t_{\exp }=2 \min$ and c) $t_{\exp }=3$ min where $t_{\exp }$ is the time after the experiment was started. $\mathrm{T}$ indicates the tectomer layer, $\mathrm{M}$ the uncovered mica regions. 
a)

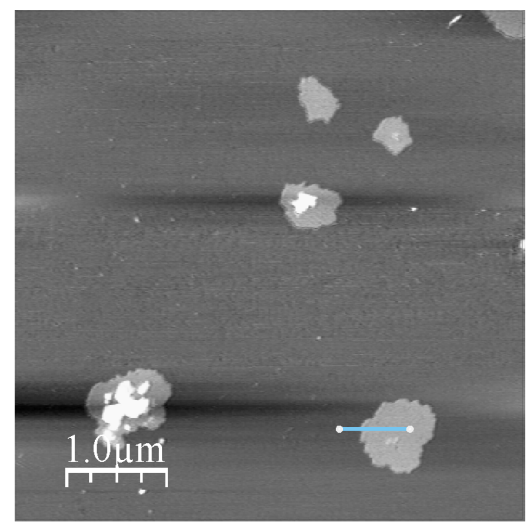

b)

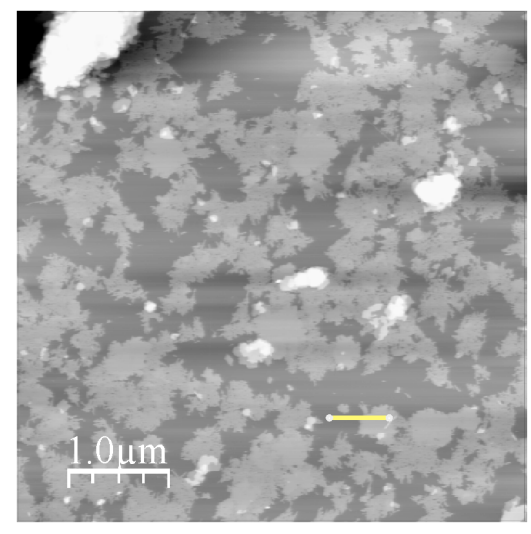

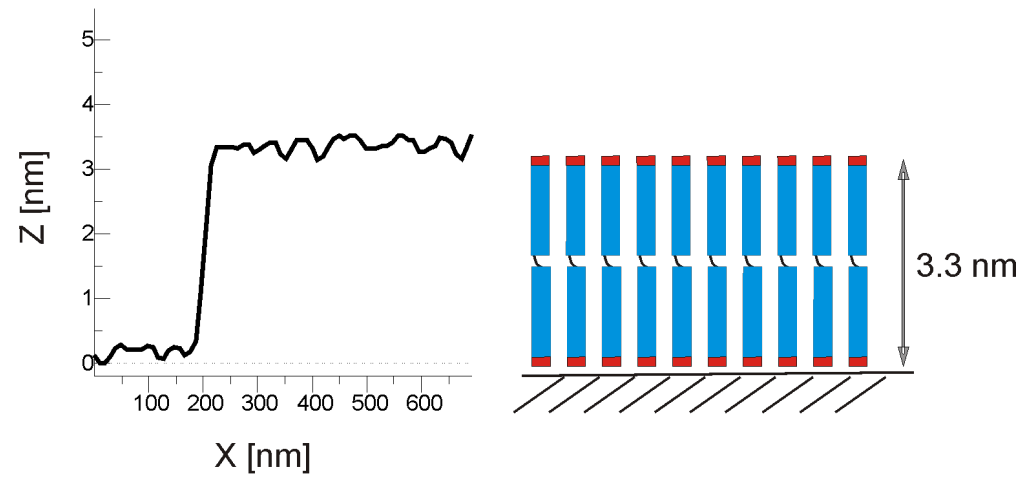

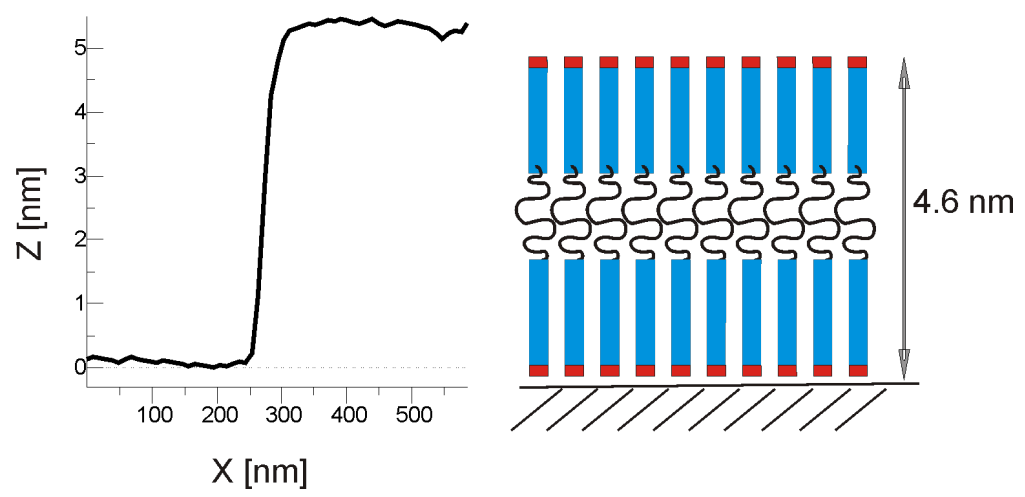

Figure 7: SFM images of associates formed by peptides a) $\mathrm{H}-\mathrm{Gly}_{5}-\mathrm{NH}\left(\mathrm{CH}_{2}\right)_{2} \mathrm{NH}-\mathrm{Gly}_{5}-\mathrm{H}$ and b) $\mathrm{H}-\mathrm{Gly}_{5}-\mathrm{NH}\left(\mathrm{CH}_{2}\right){ }_{10} \mathrm{NH}-\mathrm{Gly}{ }_{5}-\mathrm{H}($ concentration $0.1 \mathrm{mg} / \mathrm{mL}$ ) on a mica surface at $\mathrm{pH} 6.5$ with $t_{\text {exp }}=10 \mathrm{~min}$ SFM tapping mode in air, and an incubation time in solution of $1 \mathrm{~min}$. Surface profiles, schematic layer models, and their calculated heights are given on the right.

dimensions remain unchanged over time according to dynamic light scattering data.

There are no direct data pointing at the particular conformation (" $1+1$ " or " $2+0$ ") the peptide monomer has in the layer (Figure 4). The height value does not allow for the unambiguous assignment of one of the proposed models. Nevertheless, all intrinsic data supports the model "1 1 ": 1) the steps typical for a bilayer profile are not present in the SFM images, 2) intense washing does not lead to the formation of half-height structures, 3) the lack of any association on a graphite surface where the formation of " $2+0$ " is expected to be preferable (see below).

Mica promotes the assembling of amino-terminated chains due to the negative charge of the surface. In contrast, graphite did not participate in the association of biantennary oligoglycines, we observed only irregular associates formed in solution. This experimental result is unexpected, because the formation of a monolayer with the monomer conformation " $2+0$ " is favorable according to molecular dynamics simulations [13].

\section{Minimal size of $\mathrm{Gly}_{n}$ fragment providing association}

In the case of biantennary molecules association formally starts from the value $n=4$, but, in fact, this value is supposedly equal to 8 because biantennary peptides form a polyglycine structure in the extended conformation " $1+1$ ". It is noteworthy that related polymers, nylons with the formula $-\mathrm{NH}\left(\mathrm{CH}_{2}\right)_{\mathrm{x}} \mathrm{CO}$ - are known to form a PG II structure [14], i.e., additional methylene groups $\left(-\left(\mathrm{CH}_{2}\right)_{\mathrm{X}}\right.$ - instead of $\left.-\mathrm{CH}_{2}-\right)$ have no significant influence on its ability to form PG II. The association of tri- and tetraantennary peptides leads to structures with the monomer conformations " $2+2$ " and " $3+0$ ", respectively. The association starts from $n=7$. Presumably, the first and closest to forking Gly residue takes a distorted conformation and does not take part in the formation of hydrogen bonds with neighboring residues. In the case of tetraantennary oligoglycines the plane of one pair of antennas is rotated by $90^{\circ}$ [8] with respect to another pair, so that the glycines cannot form a continuous chain. On the other hand, in the biantennary analog the chain Gly 4 -X-Gly has the ability to form a PG II structure despite the core fragment $-\left(\mathrm{CH}_{2}\right)_{n}{ }^{-}$. 


\section{The nature of the core fragment $X$ in $\mathrm{H}-\mathrm{Gly}_{n}-\mathrm{X}-\mathrm{Gly}_{n}-\mathrm{H}$}

Biantennary molecules with core $\mathrm{C}_{10}$ form tectomers on a mica surface more readily than the molecules with core $\mathrm{C}_{2}$ and an equal number of glycines. The more flexible core $\mathrm{C}_{10}$ should lead to a entropy driven destabilization. The opposite effect observed in reality is most probably caused by van der Waals interactions of hydrophobic fragments $\mathrm{C}_{10}$ closely situated in the PG II structure. The oligoethylene glycol core abolishes the formation of a PG II structure, presumably due to competitive hydrogen bonding with spatially close oligoglycine fragments.

\section{Spontaneous and surface-promoted association}

The formation of tectomers on mica proceeds considerably more rapidly than association in solution (the formation of associates in solutions just starts when assembling on the surface is already finished), i.e., the mica surface obviously plays an active role in the process. Tectomer growth starts from the formation of islet structures that increase in lateral direction and cover the whole surface in an even layer. This growth is limited only by the dimensions of the support itself. It should be noted that graphite, in contrast to mica, does not promote association.

\section{Effect of $\mathrm{pH}$ value}

Depending on the $\mathrm{pH}$ value, the free terminal group of the oligoglycine chain can be heavily charged, weakly charged, or neutral. In acidic solutions antennas are repulsed due to the positive charge, which hinders tectomer assembly or even abolishes it. The $\mathrm{pH}$ value effects not only the ability to assemble but also the morphology of forming supramers. Thus, in neutral solutions biantennary oligoglycines form multilayer tectomers. The process is unstoppable at the stage of the monolayer formation. At the same time, monolayer tectomers are exclusively formed in basic solutions.

\section{Concentration range}

Most parts of the experiments were carried out in the concentration range of $0.1-1.0 \mathrm{mg} / \mathrm{mL}$. A concentration of $0.1 \mathrm{mg} / \mathrm{mL}$ was used for the adequate comparison of association of all investigated peptides. The association in the liquid phase proceeds slower at low concentrations leading to an increased size of the formed supramers.

In summary, based on our investigations related to unglycosylated molecules we can conclude that the association of biantennary oligoglycines is affected by several factors. 1) Mica but not graphite promotes the formation of tectomers. 2) The spatial organization of oligoglycine molecules in supramers corresponds to PG II conformation. 3) Not less than four glycine residues in each of two antennas are required for the assem- bling of monomer layers into surface tectomer layers or into long-living associates in solution. 4) Oligoethylene glycol core 'inhibits' the association both in the liquid phase and on a mica surface.

\section{Antiviral activity of glycoderivatives}

The idea of antiadhesion influenza virus therapy is based on the inhibition or the blocking of the binding of the influenza virus with target cells [15]. Monovalent oligosaccharides are incapable of an efficient competition for analogous glycans on the cell surface due to the low binding constant with viral hemagglutinin. An attractive way of increasing the affinity of a blocker (inhibitor) is the design of multivalent receptor analogs such as the oligoglycine-based tectomers described above. A first success for an application in this regard was achieved by inhibiting the influenza virus by sialo derivatives of the associating tetraantennary peptides, which demonstrated an antiviral activity three orders of magnitude higher than the activity of non-associating analogs [2]. Similar triantennary molecules with sialo-glycan located in the molecule "head", however, appear to display a low activity [16]. Thus, it was interesting to study the antiviral activity of sialo derivatives of biantennary oligoglycines in relation to their propensity to associate in aqueous solutions.

The fact that a sialylated biantennary peptide is capable of association in an aqueous solution similarly to glycan-free peptides is confirmed by DLC data. The average size of the sialoglycopeptide aggregates in aqueous solution was about $1 \mu \mathrm{m}$ (data not shown).

The antiviral activity of biantennary glycopeptides was studied by means of a fetuin binding inhibition test (FBI-test) [17] (the glycoprotein fetuin contains several sialylated carbohydrate chains). In this test, the glycopeptides inhibited the binding of a fetuin peroxidase conjugate to a virus immobilized on a plastic (related to the corresponding monomer). Results are given in Table 1 . The activity of associating sialooligoglycines with core $\mathrm{C}_{2}$ was only 3-6 times higher than the activities of their nonassociated counterparts $(n=2-4)$ and the monomeric reference sialoside, Neu5Ac $\alpha B n$. The compound with core $\mathrm{C}_{10}$ and $n=4$ demonstrated the highest activity from the studied biantennary glycopeptides, which was 50 times higher than the activity of the monomer. The activity of bivalent derivatives with core OEG and $n=2-5$ did not exceed that of monovalent sialoside. However, the activity increased dramatically when $n=6$ (up to 50 times), although it was still orders of magnitude smaller compared to the high activity of polymeric inhibitors [18]. As sialooligoglycines of the OEG series did not associate in aqueous solution, we suppose that the reason for the increased activity is related to a critical distance, which facilitates the real- 
Table 1: Relative activity of biantennary glycopeptides in the influenza virus receptor binding inhibition assay [17].

\begin{tabular}{|c|c|c|c|}
\hline Compound $^{a}$ & $\begin{array}{c}\text { Core, } \mathrm{X} \text { ( } n, \text { number of glycine residues in } \\
\text { antenna) }\end{array}$ & Virus & Relative activity \\
\hline \multirow[t]{2}{*}{ Neu5AcaOBn } & & & $1(150)^{b}$ \\
\hline & $\mathrm{C}_{2}(2-4)$ & & 1 \\
\hline \multirow[t]{3}{*}{ Neu5Aca-sp1-Gly ${ }_{n}-\mathrm{X}-\mathrm{Gly}_{n}$-sp1-Neu5Aca } & $\mathrm{C}_{2}(5)$ & & 3 \\
\hline & $\mathrm{C}_{2}(6)$ & $(\mathrm{A} / \mathrm{H} 3 \mathrm{~N} 2 / 29 / 90)$ & 6 \\
\hline & $\mathrm{C}_{10}(1-3)$ & & 1 \\
\hline \multirow[t]{2}{*}{ Neu5Aca-sp1-Gly ${ }_{n}-\mathrm{X}-\mathrm{Gly}_{n}$-sp1-Neu5Aca } & $\mathrm{C}_{10}(4)$ & & 50 \\
\hline & $\mathrm{C}_{10}(5)$ & & 25 \\
\hline \multirow[t]{2}{*}{ 6'SLN } & & & $1(150)^{b}$ \\
\hline & $\operatorname{OEG}(2,4)$ & \multirow{3}{*}{$(\mathrm{A} / \mathrm{H} 1 \mathrm{~N} 1 / \mathrm{NIB} 23)$} & 1 \\
\hline \multirow[t]{2}{*}{ 6'SLN-sp2-Gly ${ }_{n}-X_{-}-l_{1} y_{n}-s p 2-6{ }^{\prime S L N}$} & OEG (5) & & 1 \\
\hline & OEG (6) & & 40 \\
\hline \multirow[t]{2}{*}{ 3'SL } & & \multirow{4}{*}{$(\mathrm{A} / \mathrm{H} 5 \mathrm{~N} 2)$} & $1(150)^{b}$ \\
\hline & OEG $(2,4)$ & & 1 \\
\hline \multirow[t]{2}{*}{ 3'SL-sp3-Gly ${ }_{n}-\mathrm{X}$-Gly ${ }_{n}$-sp3-3'SL } & OEG (5) & & 1 \\
\hline & OEG (6) & & 50 \\
\hline
\end{tabular}

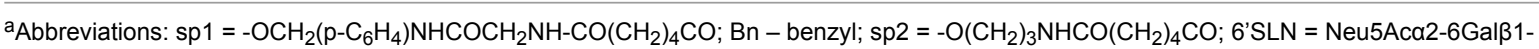

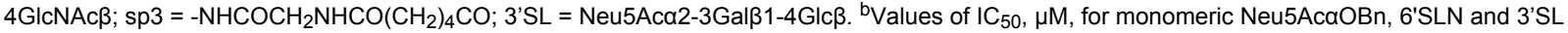
are given in parentheses.

ization of a divalent interaction of this bivalent molecule with a viral hemagglutinin. Indeed, a simple calculation demonstrates that this distance in a maximally extended molecule with $n=6$ is about $100 \AA$. This distance value corresponds to the distance between the carbohydrate binding sites in one molecule of a hemagglutinin homotrimer and slightly exceeds the distance between a couple of hemagglutinin trimmers, which are closely situated on the virion surface.

\section{Experimental}

Reagents and solvents were bought from Merck and Sigma-Aldrich. Activated esters BocGlyONSu and BocGly $_{2} \mathrm{ONSu}$ were prepared as described earlier [9] from glycine or glycylglycine (Acros). Ethylenediamine and 1,10diaminodecane were supplied from Sigma-Aldrich, and diamine $\mathrm{NH}_{2}\left(\mathrm{CH}_{2} \mathrm{CH}_{2} \mathrm{O}\right)_{3} \mathrm{CH}_{2} \mathrm{CH}_{2} \mathrm{NH}_{2}(\mathbf{1})$ was synthesized from ditosylate TosO $\left(\mathrm{CH}_{2} \mathrm{CH}_{2} \mathrm{O}\right)_{3} \mathrm{CH}_{2} \mathrm{CH}_{2} \mathrm{OTos}$ (Sigma-Aldrich) according to the described methods $[7,8]$.

Silica gel (Kieselgel 60, Merck, Germany) was used for lowpressure column chromatography. Sephadex LH-20 (Pharmacia Biotech, Austria) was employed for gel chromatography. Thinlayer chromatography (TLC) was performed on foil plates covered with silica gel (Kieselgel 60, Merck, Germany).

${ }^{1} \mathrm{H}$ NMR spectra were recorded on a Bruker spectrometer (600, $700,800 \mathrm{MHz})$ at $303 \mathrm{~K}$. Chemical shifts $(\delta)$ for characteristic signals in ${ }^{1} \mathrm{H}$ NMR spectra are given in ppm and spin-spin coupling constants $(J)$ in Hz. The scale of the chemical shifts was calibrated against the signals of residual protons of solvents $\left(\mathrm{CDCl}_{3}: \delta 7.26\right.$ ppm; DMSO- $d_{6}: \delta 2.50$ ppm; $\left.\mathrm{D}_{2} \mathrm{O}: \delta 4.75 \mathrm{ppm}\right)$. Mass-spectra were recorded on the time-of-flight spectrometer Vision-2000 (Thermo Bioanalysis, UK) with MALDI with 2,6dihydroxybenzoic acid as reference. Raman spectra were recorded on a spectrometer Ramanor HG-2S (Jobin Yvon) with the monochromator Anaspec 300S and $\operatorname{argon}(\lambda=514.5 \mathrm{~nm}$, Spectra Physics, model 164-03).

\section{Synthesis of biantennary oligoglycines}

Protocol 1: Elongation of the oligoglycine chain (Boc-Gly ${ }_{n} \mathrm{NH}-$ $\mathrm{X}-\mathrm{NHGly}_{n}$-Boc; $n=1-7, \mathrm{X}=\mathrm{C}_{2}, \mathrm{C}_{10}$ and OEG). $\mathrm{Et}_{3} \mathrm{~N}$ ( $8 \mathrm{mmol}$ ) followed by BocGlyONSu or BocGly $2 \mathrm{ONSu}$ ( $3 \mathrm{mmol})$ were added to a solution of diamine $(1 \mathrm{mmol})$ in dimethyl sulfoxide (DMSO; $5 \mathrm{~mL}$ ). The reaction mixture was stirred until the disappearance of the starting diamine (1-24 h, TLC control) and the solvent was removed under vacuum. The dry residue was suspended in methanol, filtered, dissolved in water, sedimentated with methanol, and dried in vacuo.

Protocol 2: Preparation of oligoglycines ( $\mathrm{HCl} \cdot \mathrm{Gly}_{n} \mathrm{NH}-\mathrm{X}-$ $\mathrm{NHGly}_{n} \cdot \mathrm{HCl} ; n=1-7, \mathrm{X}=\mathrm{C}_{2}, \mathrm{C}_{10}$ and $\left.\mathrm{OEG}\right)$. The Boc-derivative $(0.5 \mathrm{mmol})$ was dissolved in trifluoroacetic acid $(5 \mathrm{~mL})$, the reaction mixture was kept for $2 \mathrm{~h}$ at room temperature, co-evaporated with toluene $(2 \times 10 \mathrm{~mL})$ and $1 \mathrm{M} \mathrm{HCl}$ aqueous solution 
$(1-2 \mathrm{~mL})$, and finally with a mixture $\mathrm{iPrOH} /$ methanol $1: 1$ $(2 \times 10 \mathrm{~mL})$. The obtained product was sedimentated from the aqueous solution by the addition of methanol and dried in vacuo.

\section{Synthesis of associating glycopeptides}

Protocol 3: Neu5Ac $\alpha$-sp1-ONp, 3'SL-sp3-ONp or 6'SLN-sp2ONp $(4 \mu \mathrm{mol})$ were added to a solution of diamine $(1 \mu \mathrm{mol})$ in DMSO or saturated aqueous solution of $\operatorname{LiBr}(200 \mu \mathrm{L})$. $\mathrm{NEt}_{3}$ $(4 \mu \mathrm{mol})$ was added until a $\mathrm{pH}$ of 8 was reached, and the mixture was stirred for $24 \mathrm{~h}$ at room temperature. Exclusion chromatography on Sephadex LH-20 (eluent: $0.1 \mathrm{M}$ solution of $\mathrm{NH}_{3}$ in the mixture acetonitrile/water, 1:1). Fractions containing pure product were combined and evaporated. Dry residue was dissolved in water and freeze-dryed.

\section{Dynamic light scattering experiments}

The light scattering of aqueous solutions of biantennary oligoglycines was studied with an analyzer of submicron particle size "Malvern HPPS" (UK). After the preparation of aqueous (Milli-Q) solutions of oigoglycine salts in a concentration of $0.01-0.1 \mathrm{mg} / \mathrm{mL}$, the instrument reading was recorded $(t=0$, $\mathrm{pH}<5)$. Then, $1-2$ equiv of base $(0.1 \mathrm{M}$ aqueous solution of $\mathrm{NaHCO}_{3}$ or $\mathrm{Na}_{2} \mathrm{CO}_{3}$ ) per amino group was added to the solution of the analyzed oligoglycine salt $(t>0, \mathrm{pH} 6-8)$, and instrument readings were recorded in fixed periods of time. In the case of the formation of large associates (intense opalescence, sedimentation), whose dimensions exceeded the working limit of the instrument, the experiment was stopped.

For experiments with biantennary sialooligoglycines their aqueous (Milli-Q) solutions with a concentration of $0.1 \mathrm{mg} / \mathrm{mL}$ were used.

\section{Scanning force microscopy (SFM)}

The samples were imaged with a Nanoscope IIIa instrument (Digital Instruments, USA). Commercial silicon nitride cantilevers with force constants of $0.06,0.12$, and $0.32 \mathrm{Nm}^{-1}$ were used for the measurements in contact mode in liquid cell. Cantilevers with a resonance frequency of about $300 \mathrm{kHz}$ and a force constant of $42 \mathrm{Nm}^{-1}$ were used for the SFM tapping mode in air. Software WSxM (Nanotec Electronica, Spain) was employed for the image treatment. Pure water (Fluka) was used for the preparation of solutions.

Scanning in air. 1-2 equiv of $0.1 \mathrm{M}$ of aqueous solution of $\mathrm{NaHCO}_{3}$ or $\mathrm{Na}_{2} \mathrm{CO}_{3}$ per amino group $(\mathrm{pH} \sim 6-8)$ was added for the deprotonation to a freshly prepared solution of oligoglycine salt $(0.1-1.0 \mathrm{mg} / \mathrm{mL} ; \mathrm{pH}<5)$, and incubated for a specified time period in the range of 0 to $90 \mathrm{~min}$. Then the solution was applied on the freshly cleaved mica or graphite, and kept for a specified period of time within the range of 0 to $10 \mathrm{~min}$. Liquid was removed from the surface by spin coating or in nitrogen flow. Structures formed on the surface were visualized in tapping mode SFM.

Scanning in liquid cell. A plate of freshly cleaved mica $\left(1 \times 1 \mathrm{~cm}^{2}\right)$ was placed in a liquid cell. The cell was filled with water $(25 \mu \mathrm{L})$ and the instrument was set up. Then, water was changed with a freshly prepared solution of deprotonated peptide (see scanning in air above) and the surface was scanned in contact mode SFM in fixed time periods.

The influenza virus receptor-binding inhibition assay was carried out as described in [17].

\section{Supporting Information}

\section{Supporting Information File 1}

Descriptions of the synthesis of individual compounds.

[http://www.beilstein-journals.org/bjoc/content/

supplementary/1860-5397-10-140-S1.pdf]

\section{Acknowledgments}

This study was partly supported by the Russian Academy of Sciences Presidium Program Molecular and Cell Biology. The authors would like to thank Dr. Ekaterina A. Obraztsova for the Raman analysis and Dr. Galina V. Pazynina for valuable discussions about the experimental design and the results.

\section{References}

1. Tsygankova, S. V.; Chinarev, A. A.; Tuzikov, A. B.; Gambaryan, A. S.; Bovin, N. V. "Self-assembling glycopeptides" presented at the 17th European Carbohydrate Symposium "EuroCarb17", Tel Aviv, Israel, July 7-11, 2013, P-55.

2. Tuzikov, A. B.; Chinarev, A. A.; Gambaryan, A. S.; Oleinikov, V. A.; Klinov, D. V.; Matsko, N. B.; Kadykov, V. A.; Ermishov, M. A.; Demin, I. V.; Demin, V. V.; Rye, P. D.; Bovin, N. V. ChemBioChem 2003, 4, 147-154. doi:10.1002/cbic.200390025

3. Bovin, N. V.; Tuzikov, A. B.; Chinarev, A. A. Nanotechnologies in Russia 2008, 3, 291-302. doi:10.1134/S1995078008050042

4. Bamford, C. H.; Brown, L.; Cant, E. M.; Elliott, A.; Hanby, W. E.; Malcolm, B. R. Nature 1955, 176, 396-397. doi:10.1038/176396a0

5. Crick, F. H. C.; Rich, A. Nature 1955, 176, 780-781. doi:10.1038/176780a0

6. Bovin, N. V.; Tuzikov, A. B.; Chinarev, A. A.; Gambaryan, A. S. Glycoconjugate J. 2004, 21, 471-478. doi:10.1007/s10719-004-5537-3

7. Katritzky, A. R.; Singh, S. K.; Meher, N. K.; Doskocz, J.; Suzuki, K.; Jiang, R.; Sommen, G. L.; Ciaramitaro, D. A.; Steel, P. J. ARKIVOC 2006, (v), 43-62. doi:10.3998/ark.5550190.0007.505 
8. Katritzky, A. R.; Meher, N. K.; Hanci, S.; Gyanda, R.; Tala, S. R.; Mathai, S.; Duran, R. S.; Bernard, S.; Sabri, F.; Singh, S. K.; Doskocz, J.; Ciaramitaro, D. A. J. Polym. Sci., Part A: Polym. Chem. 2008, 46, 238-256. doi:10.1002/pola.22376

9. Gershkovich, A. A.; Kibirev, V. C. Chemical synthesis of peptides; Naukova Dumka: Kiev, Ukraine, 1992.

10. Chinarev, A. A.; Tuzikov, A. B.; Gambaryan, A. S.; Matrosovich, M. N.; Imberty, A.; Bovin, N. V. In Sialobiology and Other Novel Forms of Glycosylation; Ynoue, Y.; Lee, Y. C.; Troy, F. A., II., Eds.; Gakushin Publishing Co.: Osaka, 1999; pp 135-143.

11. Bovin, N. V.; Chinarev, A. A.; Tuzikov, A. B. Multiligand constructs. WO Patent WO/2010/043230, Oct 13, 2008.

12. Krimm, S.; Bandekar, J. In Advanced Protein Chemistry; Anfinsen, C. B.; Edsall, J. T.; Richards, F. M., Eds.; Academic Press: New York; Vol. 38, pp 181-364.

13. Gus'kova, O. A.; Khalatur, P. G.; Khokhlov, A. R.; Chinarev, A. A.; Tsygankova, S. V.; Bovin, N. V. Russ. J. Bioorg. Chem. 2010, 36, 574-580. doi:10.1134/S1068162010050043

14. Bella, J.; Puiggali, J.; Subirana, J. A. Polymer 1994, 35, 1291-1297. doi:10.1016/0032-3861(94)90026-4

15. Mammen, M.; Choi, S.-K.; Whitesides, G. M. Angew. Chem., Int. Ed. 1998, 37, 2754-2794. doi:10.1002/(SICI)1521-3773(19981102)37:20<2754::AID-ANIE2754>3 .0.CO;2-3

16. Chugunov, P. A.; Chinarev, A. A.; Tuzikov, A. B.; Formanovsky, A. A.; Prokhorov, V. V.; Gambaryan, A. S.; Bovin, N. V. Mendeleev Commun. 2009, 19, 62-63. doi:10.1016/j.mencom.2009.03.002

17. Gambaryan, A. S.; Matrosovich, M. N. J. Virol. Methods 1992, 39, 111-123. doi:10.1016/0166-0934(92)90130-6

18. Gambaryan, A. S.; Tuzikov, A. B.; Piskarev, V. E.; Yamnikova, S. S.; Lvov, D. K.; Robertson, J. S.; Bovin, N. V.; Matrosovich, M. N. Virology 1997, 232, 345-350. doi:10.1006/viro.1997.8572

\section{License and Terms}

This is an Open Access article under the terms of the Creative Commons Attribution License (http://creativecommons.org/licenses/by/2.0), which permits unrestricted use, distribution, and reproduction in any medium, provided the original work is properly cited.

The license is subject to the Beilstein Journal of Organic Chemistry terms and conditions:

(http://www.beilstein-journals.org/bjoc)

The definitive version of this article is the electronic one which can be found at: $\underline{\text { doi: } 10.3762 / \text { bjoc. } 10.140}$ 